\title{
Nitrogen Losses in Paddy Field Drainage Modified by Different Water Level Regulations
}

\author{
Shizong Zheng ${ }^{1,2}$, Menghua Xiao ${ }^{2,3 *}$, Zimei Miao ${ }^{3}$ \\ ${ }^{1}$ State Key Laboratory of Water Resources and Hydropower Engineering Science, \\ Wuhan University, 430072, P.R. China \\ ${ }^{2}$ Zhejiang Institute of Hydraulics and Estuary, 310020, P.R. China \\ ${ }^{3}$ Research Center of Fluid Machinery Engineering and Technology, \\ Jiangsu University, 212013, P.R. China
}

Received: 13 November 2016

Accepted: 23 November 2016

\begin{abstract}
Nitrogen losses from farmland, through improper drainage and rainstorm runoff, cause non-point source pollution and limit sustainable agriculture development. We determined the effects of controlled drainage (CTD) and conventional drainage (CVD) on migration responses, the transformation of nitrogen, and $\mathrm{NH}_{4}{ }^{+} \mathrm{N}$ and $\mathrm{NO}_{3}^{-}-\mathrm{N}$ losses. The results showed that four days after a rainstorm, compared with day one, $\mathrm{NH}_{4}^{+}-\mathrm{N}$ and $\mathrm{NO}_{3}^{-}-\mathrm{N}$ decreased by ranges of $28.7-46.7 \%$ and $7.5-47.5 \%$ in $\mathrm{CTD}$, which was significantly higher than CVD. CTD also significantly reduced $\mathrm{NH}_{4}^{+}-\mathrm{N}$ and $\mathrm{NO}_{3}^{-}-\mathrm{N}$ losses in field drainage compared with CVD. $\mathrm{NH}_{4}{ }^{+}-\mathrm{N}$ was reduced by $66.72 \%$ and $\mathrm{NO}_{3}^{-}-\mathrm{N}$ reduction was $55.56 \% . \mathrm{NH}_{4}^{+}-\mathrm{N}$ contributed most to nitrogen losses, while $\mathrm{NO}_{3}^{-}-\mathrm{N}$ contributed less. Following rainstorm events, varying the water level using CVD and CTD had significant effects on $\mathrm{NH}_{4}^{+}-\mathrm{N}$ and $\mathrm{NO}_{3}^{-}-\mathrm{N}$ concentrations. The DRAINMOD-II model was used to simulate $\mathrm{NH}_{4}^{+}-\mathrm{N}$ and $\mathrm{NO}_{3}^{-}-\mathrm{N}$ levels. It indicated that the observed and simulated values of $\mathrm{NH}_{4}^{+}-\mathrm{N}$ and $\mathrm{NO}_{3}^{-}-\mathrm{N}$ concentrations in both $\mathrm{CVD}$ and CTD were fitted better. Lastly, the innovation of this study was that it focused on nitrogen concentrations and load changes in paddy field drainage after rainstorms, firstly using the DRAINMOD-N II model to simulate $\mathrm{NH}_{4}^{+}-\mathrm{N}$ and $\mathrm{NO}_{3}^{-}-\mathrm{N}$ concentration changes under field scale. It further validated the pollution-reduction effect under water level control in the paddy field. Also, it improved the irrigation-drainage system of paddy rice and provided a scientific basis for optimizing irrigation-drainage project design in rice irrigation district.
\end{abstract}

Keywords: water level control, $\mathrm{NH}_{4}^{+}-\mathrm{N}, \mathrm{NO}_{3}^{-}-\mathrm{N}$, non-point source pollution, DRAINMOD-N II

\section{Introduction}

Eutrophication can result from inadequate treatment of water pollutants, and it is an important environmental

*e-mail: menghuaxiao@aliyun.com issue. Agricultural non-point source pollution is a key contributor to the eutrophication process. Fertilizers, pesticides, and other chemicals used in agriculture can enter surface water through farmland drainage and surface runoff from precipitation or irrigation, resulting in pollution of rivers, lakes, and port areas [1-2]. Runoff and drainage are key sources of groundwater pollution 
and cause degradation of wetlands. Nitrogen compounds comprise the majority of agricultural fertilizers, and nitrogen is the most important nutrient used by crop plants [3]. Nitrogen loss by runoff causes economic losses, environmental pollution, and threatens human health. In conventional farmland irrigation and drainage, drainage water carries large amounts of nutrients directly into the surrounding environment, causing soil and water pollution as well as eutrophication of rivers and lakes [4]. Nitrogen loss amounts per unit area of paddy fields, through leakage and runoff, were four times greater than losses from upland rice production areas. Paddy field irrigation methods therefore pose a serious hazard to rural water environments. Therefore, controlled irrigation-drainage techniques have been implemented through regulation of the water levels in paddy fields [5-7]. Controlled irrigation-drainage increases water use efficiency through water level control while ensuring normal rice yields [89]. Water level control reduces levels of nitrogen and phosphorus in drainage and effectively reduces farmland losses of nitrogen and phosphorus [10-12].

The transport and transformation of agricultural non-point source pollution is associated with natural environmental factors, agricultural management, and engineering. This process involves multi-level, multiobjective, real-time, and temporality increasingly sensitive multi-factor interactions within complex systems [13]. Many laboratory and field experiments have been conducted on nitrogen and phosphorus transport mechanisms and corresponding control measures. Because these studies have typically focused on only one or a few selected factors, it is difficult to extrapolate the results to other field situations [14]. A quantitative analysis model can be an effective tool for the study of agricultural water, fertilizer management, and nitrogen pollution control. Computer simulation can be used to evaluate agricultural management alternatives related to soil nitrogen transport [15]. A field-scale model is the most widely used. This model does not consider climatic conditions, agricultural land use, soil texture, spatial variability of soil, water management, land use, or soil texture conditions. However, it can accurately describe and evaluate the effects of different agricultural management practices on soil erosion and nitrogen transport, and this provides input for large-scale, GIS-based parametric model studies [1618].

Field-scale model development and applications are areas of active current research. These models include CREAMS (chemicals, runoff, and erosion from agricultural management systems), GLEAMS (groundwater loading effects of agricultural management systems), DRAINMOD-N, LEACHM (leaching estimation and chemistry model), RZWQM (root zone water quality model), and EPIC (erosion/ productivity impact calculator) [19]. Breve developed the DRAINMOD-N model based on DRAIN-MOD [20]. DRAINMOD-N was used to study vertical migration of water and nitrogen in one-dimensional unsaturated zone farmland, and vertical and lateral migration of water and nitrogen in a two-dimensional saturated zone. DRAINMOD-N has been extensively used worldwide. The main model input parameters include weather, soils, crops, drainage system design, and nitrogen transport parameters. DRAINMOD-NII has been expanded to enable description of the transformation and migration of organic fertilizer nitrogen. It has been tested and applied in many countries and regions, and has provided accurate prediction and high significant confidential level [21-22].

This study focuses on nitrogen concentrations and load changes in paddy drainage following storms and through the use of different water level controls. We used the DRAINMOD-N II model to simulate $\mathrm{NH}_{4}{ }^{+} \mathrm{N}$ and $\mathrm{NO}_{3}^{-}-\mathrm{N}$ concentration changes on a farmland scale. This approach is meaningful for rational irrigation and drainage schemes and non-point source pollution control, and it also provides basic data for the development of rice irrigation and drainage strategies.

\section{Materials and Methods}

\section{Experimental Site and Soil Properties}

The experiment was conducted from October 2011 to October 2012 in the Yunnan Irrigation District, Sucheng, Jiangsu Province, China. The experimental site is located in a warm temperate zone of monsoon climate. The mean annual rainfall is $892.3 \mathrm{~mm}$, and rainfall occurs on an average of $120 \mathrm{~d}$ per year. Rain amounts during the main monsoon season account for nearly $70 \%$ of the annual total. The mean annual evaporation is $900 \mathrm{~mm}$, mean annual temperature is $14.1^{\circ} \mathrm{C}$, and the highest mean monthly temperature is $27.2^{\circ} \mathrm{C}$. The mean hours of annual sunshine is $2,314 \mathrm{~h}$ and the annual frost-free period is $211 \mathrm{~d}$. The topsoil $(0-30 \mathrm{~cm}) \mathrm{pH}$ is 6.95 and it contains $10.45 \mathrm{~g} \mathrm{~kg}^{-1}$ organic matter, $0.8945 \mathrm{~g} \mathrm{~kg}^{-1}$ total nitrogen, $27.95 \mathrm{mg} \mathrm{kg}^{-1}$ available nitrogen, $0.34 \mathrm{~g} \mathrm{~kg}^{-1}$ total phosphorus, and $12.2 \mathrm{mg} \mathrm{kg}^{-1}$ available phosphorus.

\section{Experimental Design}

Early Japonica rice was grown according to local methods. There were two water level control programs (treatments): conventional irrigation-drainage (CVD) and controlled irrigation-drainage (CTD). Each treatment had three replications. At $50 \mathrm{~cm}$ below the balk, each experimental plot had plastic isolating film to prevent water exchange. Fertilizer regime was determined according to local methods. There were three fertilizer applications. These were basal fertilizer on 25 June, tillering fertilizer on 9 July, and panicle fertilizer on 10 August. Pure nitrogen amounts were, respectively, $120 \mathrm{~kg} / \mathrm{hm}^{2}$ (30\%), $60 \mathrm{~kg} / \mathrm{hm}^{2}(17 \%)$, and $60 \mathrm{~kg} / \mathrm{hm}^{2}(17 \%)$, for an annual total of $240 \mathrm{~kg} / \mathrm{hm}^{2}$. Each treatment was applied with $50 \mathrm{~kg} / \mathrm{hm}^{2} \mathrm{P}_{2} \mathrm{O}_{5}$ and $\mathrm{K}_{2} \mathrm{O}$. Water management of paddy fields with CVD was based on local methods. The water level control indicator of CVD is shown in Table 1 and CTD is shown in Table 2. 
Table 1. Water level control indicators at rice growth stages under CVD mode.

\begin{tabular}{|c|c|c|c|c|c|c|}
\hline \multirow{2}{*}{ Growth stage } & \multirow{2}{*}{$\begin{array}{l}\text { Regreening } \\
\text { stage }\end{array}$} & \multicolumn{2}{|c|}{ Tillering stage } & \multirow{2}{*}{$\begin{array}{c}\text { Jointing } \\
\text {-booting stage }\end{array}$} & \multirow{2}{*}{$\begin{array}{c}\text { Heading } \\
\text {-flowering stage }\end{array}$} & \multirow{2}{*}{$\begin{array}{l}\text { Milking } \\
\text { stage }\end{array}$} \\
\hline & & Early stage & Later stage & & & \\
\hline Upper water level limit (mm) & 30 & 30 & 0 & 30 & 30 & 30 \\
\hline Lower water level limit (mm) & 10 & 0 & $0.6 \theta$ & 0 & 0 & 0 \\
\hline The water depth allowed (mm) & 50 & 50 & 0 & 70 & 70 & 70 \\
\hline
\end{tabular}

Notes: $\theta$ is the observed saturated water content of bulk soil in the root zone

Table 2. Water level control indicators at rice growth stages under CTD mode.

\begin{tabular}{|c|c|c|c|c|}
\hline Growth stage & Tillering stage & Jointing-booting stage & $\begin{array}{c}\text { Heading-flowering } \\
\text { stage }\end{array}$ & Milking stage \\
\hline Upper water level limit(mm) & 30 & 30 & 30 & 30 \\
\hline Lower water level limit(mm) & -200 & -300 & -300 & -300 \\
\hline The water depth allowed $(\mathrm{mm})$ & $100(5 \mathrm{~d})$ & $200(5 \mathrm{~d})$ & $250(5 \mathrm{~d})$ & $250(5 \mathrm{~d})$ \\
\hline
\end{tabular}

Notes: Positive value is flooding depth while negative value is the length from field surface to underground water level. Number within parentheses indicates flooding days

\section{Experiment Materials and Methods}

The losses of $\mathrm{NH}_{4}^{+}-\mathrm{N}$ and $\mathrm{NO}_{3}^{-}-\mathrm{N}$ are mass concentrations of $\mathrm{NH}_{4}^{+}-\mathrm{N}$ and $\mathrm{NO}_{3}^{-}-\mathrm{N}$ of each treatment discharged from surface water following rainstorms. This value was set at 0 , when the water level was less than the lower control limit and the amount by which the water depth exceeded the lower control limit. Water samples were collected from surface flooding by polyethylene bottles. Surface water was collected, without soil disturbance, using a 50-mL syringe. $\mathrm{NH}_{4}^{+}-\mathrm{N}$ and $\mathrm{NO}_{3}^{-}-\mathrm{N}$ in the water samples were analyzed by the indophenol blue method and the disulfonic acid phenol method using a UV-2800 spectrophotometer [23].

The DRAINMOD-N II model was used to simulate the $\mathrm{NH}_{4}^{+}-\mathrm{N}$ and $\mathrm{NO}_{3}^{-}-\mathrm{N}$ concentrations. The DRAINMOD-N II models the nitrogen and carbon cycle on the basis of DRAINMOD. The water balance results were used as input for nitrogen transport. The multiphase onedimensional convection dispersion equation was used for transport modeling of nitrogen. The multiphase onedimensional advection dispersion equation was:

$$
\begin{aligned}
\frac{\partial}{\partial_{t}}\left(\theta_{a} C_{a}+\theta_{g} C_{g}+\rho_{b} C_{s}\right) & =\frac{\partial}{\partial_{z}}\left(\theta_{a} D_{a} \frac{\partial C_{a}}{\partial_{z}}+\theta_{g} d_{g} \frac{\partial C_{g}}{\partial_{z}}\right) \\
& -\frac{\partial\left(v_{a} C_{a}\right)}{\partial_{z}}-S
\end{aligned}
$$

...where $\theta_{\mathrm{a}}$ and $\theta_{\mathrm{g}}$ are, respectively, volume fraction of liquid phase and gas in soil $\left(\mathrm{L}^{3} / \mathrm{L}^{3}\right) ; C_{\mathrm{a}}, C_{\mathrm{g}}$, and $C_{\mathrm{s}}$ are, respectively, the form of nitrogen in liquid, gas, and solid concentrations $\left(\mathrm{M} / \mathrm{L}^{3}\right) ; \rho_{\mathrm{b}}$ is referred to as the solid phase of soil dry bulk density $\left(\mathrm{M} / \mathrm{L} \cdot \mathrm{T}^{2}\right) ; D$ is the hydrodynamic dispersion coefficient $\left(\mathrm{L}^{2} / \mathrm{T}\right) ; d_{\mathrm{g}}$ is the molecular diffusion coefficient $\left(\mathrm{L}^{2} / \mathrm{T}\right) ; v_{\mathrm{a}}$ is the liquid volume flux phase $(\mathrm{L} / \mathrm{T})$; and $S$ is the source term.

The simulation evaluation index of total relative error, correlation coefficient $\mathrm{R}$, and $\mathrm{CD}$ index were further drawn into the evaluation system:

$$
\begin{gathered}
R=\sqrt{\left(\sum_{i=1}^{n}\left(O_{i}-\bar{O}\right)\left(S_{i}-\bar{S}\right)\right)^{2} / \sum_{i=1}^{n}\left(O_{i}-\bar{O}\right)^{2} \sum_{i=1}^{n}\left(S_{i}-\bar{S}\right)^{2}} \\
C D=\sum_{i=1}^{n}\left(O_{i}-\bar{O}\right)^{2} / \sum_{i=1}^{n}\left(S_{i}-\bar{O}\right)^{2}
\end{gathered}
$$

...where $O_{\mathrm{i}}$ was the observed value for the period of $i, \overline{\mathrm{O}}$ was the mean value of observation, $S_{\mathrm{i}}$ was the simulated value for the period of $i$, and $\bar{S}$ was the mean value of simulated values. $R$ reflected the correlation between simulated and observed values, and CD reflects the simulation value degree of deviation from the observed mean. The optimal value of both $R$ and $C D$ values was 1 .

\section{Statistical Analysis}

Statistical analysis was carried out by standard procedures on a randomized plot design (SPSS 19.0). Significance was calculated based on F-tests and least significant differences (LSD) at the 0.05 probability level. The DRAINMOD-N II model was used to simulate the $\mathrm{NH}_{4}^{+}-\mathrm{N}$ and $\mathrm{NO}_{3}^{-}-\mathrm{N}$ concentrations. 


\section{Results and Discussion}

Changes in $\mathrm{NH}_{4}^{+}-\mathrm{N}$ Concentrations in Paddy Drainage

$\mathrm{NH}_{4}^{+}-\mathrm{N}$ concentrations in the different treatments are shown in Fig. 1. At $1 \mathrm{~d}$ after a rainstorm, the $\mathrm{NH}_{4}^{+}-\mathrm{N}$ concentration in CVD was higher than that in CTD.
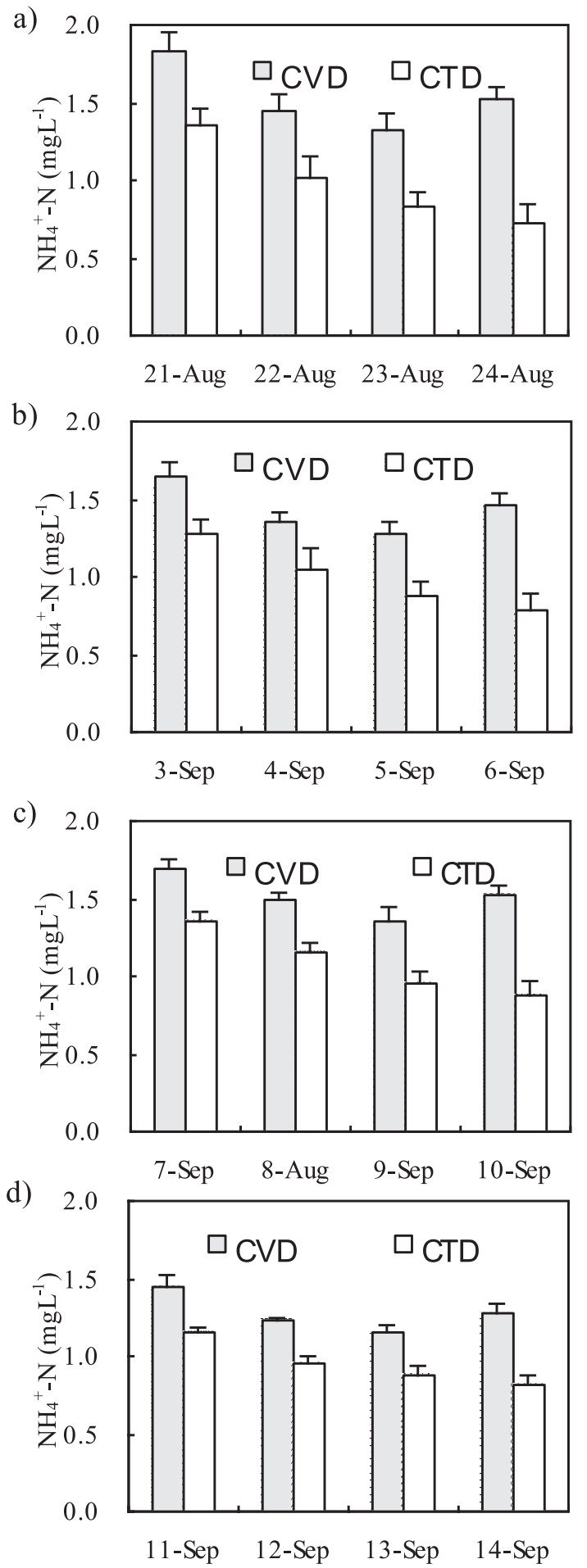

Fig. 1. Changes in $\mathrm{NH}_{4}^{+}-\mathrm{N}$ concentrations in paddy drainage after a) rainstorms-1, b) rainstorm-2, c) rainstorm-3, d) rainstorm-4.
This is mainly because the highest water storage depth allowed in CTD treatment was greater than that in CVD treatment. In CVD, the $\mathrm{NH}_{4}^{+}$-N concentration, after each rainstorm, initially decreased then increased. This is mainly because the field water level decreased gradually in $\mathrm{CVD}$, resulting in $\mathrm{NH}_{4}^{+}-\mathrm{N}$ concentration rising again at $4 \mathrm{~d}$ after the rainstorm. $\mathrm{NH}_{4}^{+}-\mathrm{N}$ concentration was decreased in CTD, indicating that CTD can effectively

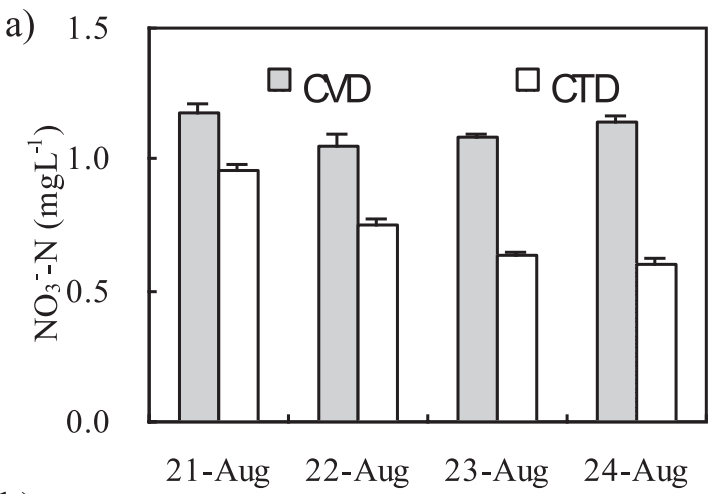

b) 1.5
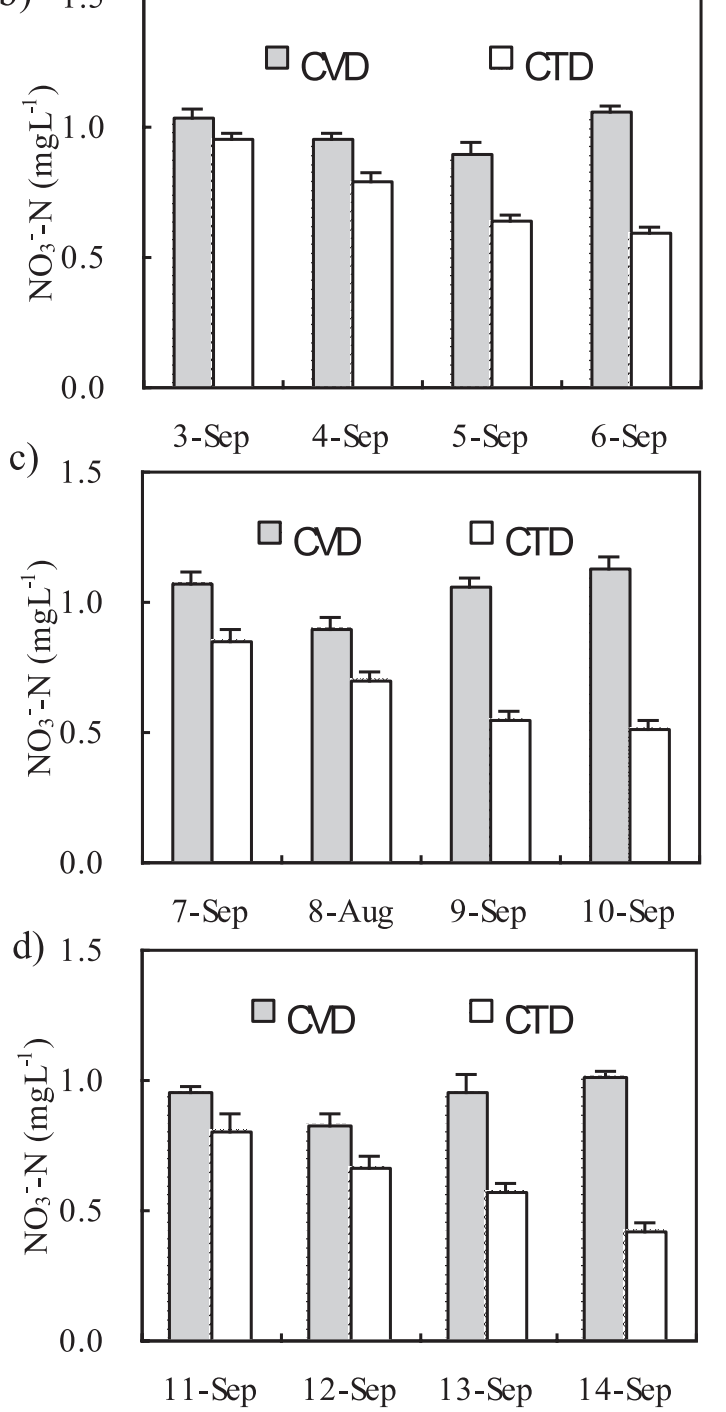

Fig. 2. Changes in $\mathrm{NO}_{3}^{-}-\mathrm{N}$ concentrations in paddy drainage after a) rainstorms-1, b) rainstorm-2, c) rainstorm-3, d) rainstorm-4. 
Table 3. Influence of different water level controls on $\mathrm{NH}_{4}^{+}-\mathrm{N}$ and $\mathrm{NO}_{3}^{-}-\mathrm{N}$ concentrations.

\begin{tabular}{|c|c|c|c|c|c|c|c|}
\hline & & \multicolumn{3}{|c|}{$\mathrm{NH}_{4}^{+}-\mathrm{N}$} & \multicolumn{3}{|c|}{$\mathrm{NO}_{3}-\mathrm{N}$} \\
\hline Rainstorm & Water level control & $\begin{array}{l}\text { Starting } \\
\left(\mathrm{mg} \mathrm{L}^{-1}\right)\end{array}$ & $\begin{array}{l}\text { Ending } \\
\left(\mathrm{mg} \mathrm{L}^{-1}\right)\end{array}$ & Sig. $\alpha$ & $\begin{array}{l}\text { Starting } \\
\left(\mathrm{mg} \mathrm{L}^{-1}\right)\end{array}$ & $\begin{array}{l}\text { Ending (mg } \\
\left.L^{-1}\right)\end{array}$ & Sig. $\alpha$ \\
\hline \multirow{2}{*}{ Rainstorm-1 } & CVD & 1.204 & 0.252 & \multirow{2}{*}{$*(p=0.020)$} & 0.504 & 0.433 & \multirow{2}{*}{$* *(p=0.005)$} \\
\hline & CTD & 0.794 & 0.084 & & 0.416 & 0.122 & \\
\hline \multirow{2}{*}{ Rainstorm-2 } & CVD & 2.106 & 0.378 & \multirow{2}{*}{$*(p=0.019)$} & 3.933 & 0.508 & \multirow{2}{*}{$* *(p=0.003)$} \\
\hline & CTD & 1.826 & 0.157 & & 2.693 & 0.236 & \\
\hline \multirow{2}{*}{ Rainstorm-3 } & CVD & 1.807 & 0.733 & \multirow{2}{*}{$*(p=0.014)$} & 3.606 & 0.461 & \multirow{2}{*}{$* *(p=0.006)$} \\
\hline & CTD & 1.852 & 0.697 & & 3.556 & 0.696 & \\
\hline \multirow{2}{*}{ Rainstorm-4 } & CVD & 3.360 & 1.024 & \multirow{2}{*}{$*(p=0.015)$} & 3.644 & 1.547 & \multirow{2}{*}{$(p=* 0.011)$} \\
\hline & CTD & 2.313 & 0.617 & & 3.565 & 1.152 & \\
\hline
\end{tabular}

Notes: * = significant at the 0.05 level.

$* *=$ significant at the 0.01 level

reduce the $\mathrm{NH}_{4}^{+}-\mathrm{N}$ concentration in drainage. The mean $\mathrm{NH}_{4}^{+}-\mathrm{N}$ concentration after each rainstorm in $\mathrm{CVD}$ was $1.53 \mathrm{mg} \mathrm{L}^{-1}, 1.44 \mathrm{mg} \mathrm{L}^{-1}, 1.52 \mathrm{mg} \mathrm{L}^{-1}$, and $1.28 \mathrm{mg} \mathrm{L}^{-1}$, respectively, while concentrations were $0.98 \mathrm{mg} \mathrm{L}^{-1}$, $1.00 \mathrm{mg} \mathrm{L}^{-1}, 1.08 \mathrm{mg} \mathrm{L}^{-1}$, and $0.95 \mathrm{mg} \mathrm{L}^{-1}$ in CTD. The CTD amounts were $63.9 \%, 69.8 \%, 71.1 \%$, and $74.5 \%$ those of CVD, respectively. Compared with $1 \mathrm{~d}$ after rainstorms, the $\mathrm{NH}_{4}^{+}-\mathrm{N}$ concentrations at $4 \mathrm{~d}$ decreased by $16.4 \%, 11.0 \%, 10.0 \%$, and $12.4 \%$, respectively, and the range of decrease was small in CVD. In CTD, decreases were $46.7 \%, 38.3 \%, 35.6 \%$, and $28.7 \%$, respectively, and the range of decrease was higher than that of the CVD treatment. $\mathrm{NH}_{4}^{+}-\mathrm{N}$ loss typically occurs though surface drainage. Large proportions of $\mathrm{NH}_{4}^{+}-\mathrm{N}$ in paddy field water comes from the slow mineralization and decomposition of organic nitrogen in the subsoil. Cui et al. have demonstrated that leaching losses of fertilizer $\mathrm{NH}_{4}^{+}-\mathrm{N}$ are very low, accounting for only $5.60-6.40 \%$ of the total leaching losses of $\mathrm{NH}_{4}^{+}-\mathrm{N}$ and $0.310-0.340 \%$ of the nitrogen input during rice growth stages [24].

\section{Changes in $\mathrm{NO}_{3}^{-}-\mathrm{N}$ Concentrations in Paddy Drainage}

$\mathrm{NO}_{3}-\mathrm{N}$ concentration in different treatments in a paddy field after a rainstorm are shown in Fig. 2. $\mathrm{NO}_{3}^{-}-\mathrm{N}$ concentrations in each treatment after rainstorms

Table 4. $\mathrm{NH}_{4}^{+}-\mathrm{N}$ and $\mathrm{NO}_{3}^{-}-\mathrm{N}$ losses in paddy drainage related to water-level controls.

\begin{tabular}{|c|c|c|c|c|}
\hline Treatment & $\begin{array}{c}\mathrm{NH}_{4}^{+}-\mathrm{N} \\
\text { losses } \\
\left(\mathrm{kg} \mathrm{ha}^{-1}\right)\end{array}$ & $\begin{array}{c}\text { The } \\
\text { proportion } \\
\text { accounting } \\
\text { for N loss } \\
(\%)\end{array}$ & $\begin{array}{c}\mathrm{NO}_{3}^{-}-\mathrm{N} \\
\text { losses } \\
\left(\mathrm{kg} \mathrm{ha}^{-1}\right)\end{array}$ & $\begin{array}{c}\text { The } \\
\text { proportion } \\
\text { accounting } \\
\text { for N loss } \\
(\%)\end{array}$ \\
\hline $\begin{array}{c}\text { CVD } \\
\text { mode }\end{array}$ & 5.80 & 53.70 & 0.63 & 5.83 \\
\hline $\begin{array}{c}\text { CTD } \\
\text { mode }\end{array}$ & 1.93 & 53.61 & 0.28 & 7.78 \\
\hline
\end{tabular}

were lower than $\mathrm{NH}_{4}^{+}-\mathrm{N}$ concentrations. The reason might be the nitrogen fertilizer type. At $1 \mathrm{~d}$ after rain, $\mathrm{NO}_{3}^{-}-\mathrm{N}$ concentration in CVD was higher than that in CTD. This is because the allowed water storage depth was greater in $\mathrm{CVD} . \mathrm{NO}_{3}^{-} \mathrm{-N}$ concentrations following each rainstorm initially decreased before increasing, and this was most evident at $1 \mathrm{~d}$. This is because the field water level in CVD gradually decreased, resulting in $\mathrm{NO}_{3}^{-}-\mathrm{N}$ concentrations increasing, while in CTD concentrations decreased. These data indicate that CVD can effectively reduce $\mathrm{NO}_{3}^{-}-\mathrm{N}$ concentrations in drainage. After each rainstorm, mean $\mathrm{NO}_{3}^{-}-\mathrm{N}$ concentration in $\mathrm{CVD}$ was $1.11 \mathrm{mg} \mathrm{L}^{-1}$, $0.99 \mathrm{mg} \mathrm{L}^{-1}, 1.04 \mathrm{mg} \mathrm{L}^{-1}$, and $0.94 \mathrm{mg} \mathrm{L}^{-1}$, respectively, while in CTD it was $0.74 \mathrm{mg} \mathrm{L}^{-1}, 0.73 \mathrm{mg} \mathrm{L}^{-1}, 0.65 \mathrm{mg} \mathrm{L}^{-1}$, and $0.61 \mathrm{mg} \mathrm{L}^{-1}$, respectively. The CTD amounts were $66.1 \%, 75.4 \%, 62.7 \%$, and $65.5 \%$ those of CVD. Compared

Table 5. Model input data of soil data of depth, water content, and hydraulic conductivity.

\begin{tabular}{|c|c|c|c|}
\hline Soil data & \multicolumn{3}{|c|}{ Value range } \\
\hline Soil depth $(\mathrm{cm})$ & $0-20$ & $20-50$ & $50-300$ \\
\hline Soil saturated water content $\theta \mathrm{s}$ & 0.360 & 0.394 & 0.410 \\
\hline $\begin{array}{c}\text { Soil participated water content } \\
\theta \mathrm{r}\end{array}$ & 0.07 & 0.10 & 0.16 \\
\hline$\alpha$ & 0.005 & 0.007 & 0.007 \\
\hline $\mathrm{n}$ & 1.725 & 1.396 & 1.749 \\
\hline $\mathrm{m}$ & 0.430 & 0.267 & 0.419 \\
\hline $\begin{array}{c}\text { Lateral saturated hydraulic } \\
\text { conductivity (cm/h) }\end{array}$ & 1.45 \\
\hline $\begin{array}{c}\text { Vertical saturated hydraulic } \\
\text { conductivity (cm/h) }\end{array}$ & \multicolumn{3}{|c|}{4.20} \\
\hline $\begin{array}{c}\text { Vertical hydraulic conductivity } \\
(\mathrm{cm} / \mathrm{h})\end{array}$ & \multicolumn{3}{|c}{285} \\
\hline
\end{tabular}

Note: $\alpha, m$ and $n$ were as statistical parameters of the soil water characteristic curve formula $\theta=\theta r+(\theta s-\theta r) /(1+|\alpha h| n)$ $\mathrm{m}, \mathrm{m}=1-1 / \mathrm{n}$. 
Table 6. Model input data of meteorological, irrigation-drainage, crops, and nitrogen transport parameters.

\begin{tabular}{|c|c|c|c|c|}
\hline Parameter type & Parameter & \multicolumn{3}{|c|}{ Selection value } \\
\hline $\begin{array}{l}\text { Meteorological } \\
\text { data }\end{array}$ & $\begin{array}{l}\text { Max and min } \\
\text { daily temperature, } \\
\text { rainfall, amount } \\
\text { of transpiration }\end{array}$ & \multicolumn{3}{|c|}{ Information provided by Sucheng District Water Authority } \\
\hline \multirow{4}{*}{$\begin{array}{l}\text { Irrigation } \\
\text { and drainage } \\
\text { parameters }\end{array}$} & \multirow{4}{*}{$\begin{array}{l}\text { The irrigation depth } \\
\text { during the growth } \\
\text { period }\end{array}$} & CVD & \multicolumn{2}{|c|}{$\begin{array}{c}\text { According to water level control in different growth periods, controls are } \\
\text { given in Table } 1 . \text { In CVD mode, when water shortage occurs, irrigation } \\
\text { water should be added to the appropriate upper limit, free draining and } \\
\text { not stored. }\end{array}$} \\
\hline & & \multirow[t]{3}{*}{ CTD } & \multicolumn{2}{|c|}{$\begin{array}{l}\text { According to water level control given in Table } 2 \text {, in CTD mode, } \\
\text { when water shortage occurs, irrigation water should be added to the } \\
\text { appropriate upper limit. When the amount of water is too great, it should } \\
\text { regulate the control gate to drain to maximum allowed water depth, and } \\
\text { the duration of submergence tolerance was less than } 5 \mathrm{~d} \text {. }\end{array}$} \\
\hline & & & Date & $\begin{array}{l}\text { Apr. } 1^{\text {st }} \text {, May. } 11^{\text {th }}, \text { June. } 26^{\text {th }} \text {, July. } 28^{\text {th }} \text {, Aug. } 23^{\text {rd }} \text {, } \\
\text { Sep. } 1^{\text {st }}, \text { Oct. } 1^{\text {st }}\end{array}$ \\
\hline & & & $\begin{array}{l}\text { Crest elevation } \\
\quad(\mathrm{cm})\end{array}$ & $40,50,80,100,120,120,40$ \\
\hline \multirow[t]{2}{*}{ Corp parameter } & \multirow[t]{2}{*}{ Rice root depth } & Date & \multicolumn{2}{|c|}{$\begin{array}{c}15 \text { April, } 1 \text { May, } 15 \text { May, } 12 \text { May, } 12 \text { July, } 2 \text { August, } 15 \text { September, } 7 \\
\text { October }\end{array}$} \\
\hline & & Root depth $(\mathrm{cm})$ & & $3,5,15,25,30,30,30,30,30$ \\
\hline $\begin{array}{l}\text { Nitrogen } \\
\text { transportation } \\
\text { parameter }\end{array}$ & $\begin{array}{l}\text { Nitrogen fertilizer } \\
\text { application }\end{array}$ & \multicolumn{3}{|c|}{$\begin{array}{c}\text { The basal, tillering and panicle fertilizations were applied on } 25 \text { June, } 9 \text { July, and } 10 \\
\text { August, respectively. Nitrogen fertilization was calculated by amounts of pure nitrogen, } \\
\text { which were, respectively, } 120 \mathrm{~kg} / \mathrm{hm}^{2}(30 \%), 60 \mathrm{~kg} / \mathrm{hm}^{2}(17 \%) \text {, and } 60 \mathrm{~kg} / \mathrm{hm}^{2}(17 \%) \text {. } \\
\text { Total nitrogen was } 240 \mathrm{~kg} / \mathrm{hm}^{2} .\end{array}$} \\
\hline
\end{tabular}

to $1 \mathrm{~d}, \mathrm{NO}_{3}^{-}-\mathrm{N}$ concentration in $\mathrm{CVD}$ was reduced by $3.4 \%$, but increased by $1.9 \%, 5.6 \%$, and $6.3 \%$ at $4 \mathrm{~d}$, while in CTD it was reduced by $37.5 \%, 37.9 \%, 40.0 \%$,
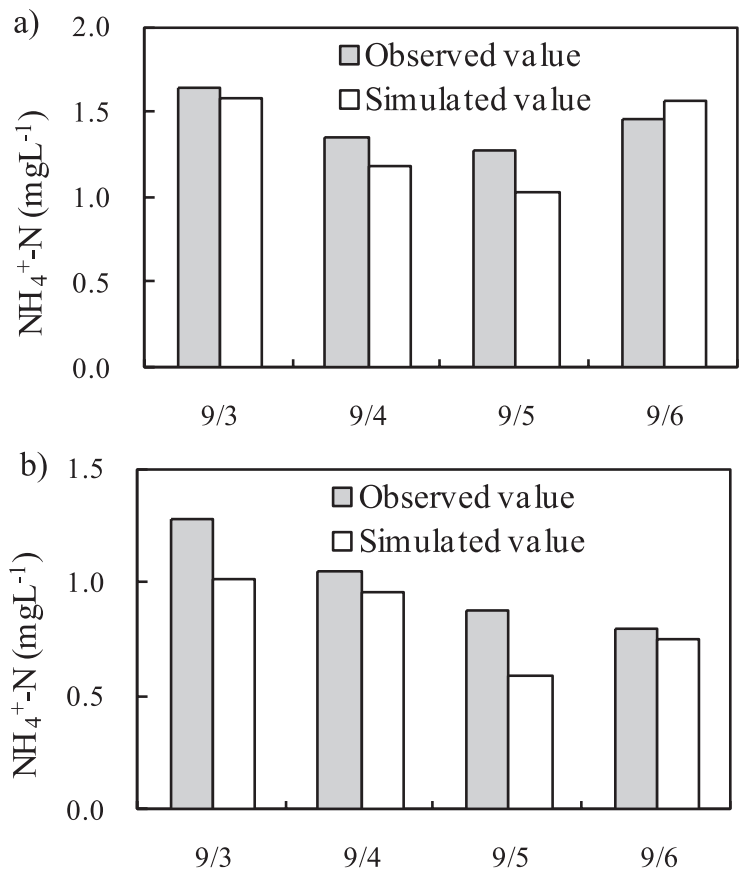

Fig. 3. Observed and simulated values of $\mathrm{NH}_{4}^{+}-\mathrm{N}$ concentrations at different water levels: a) rainstorm-2-CVD, b) rainstorm-2CTD. and $47.5 \%$. The amount of reduction was significant, indicating that water level control by CTD can help purify water and reduce $\mathrm{NO}_{3}^{-}-\mathrm{N}$ concentrations, thus reducing agricultural non-point source pollution. These results have aided plot experiment research [25]. The controlled irrigation-drainage technology index system determined by the plot experiment were perfected and popularized in the field experiment. This improved water conservation, reduced emissions, and validated the emission reduction benefits of controlled drainage [26]. The results are of great significance to the design of ecologically based irrigation district construction in China.

\section{Analysis of Different Water Control Levels on Losses of $\mathrm{NH}_{4}^{+}-\mathrm{N}$ and $\mathrm{NO}_{3}^{-}-\mathrm{N}$}

Changes in $\mathrm{NH}_{4}^{+}-\mathrm{N}$ and $\mathrm{NO}_{3}^{-}-\mathrm{N}$ concentrations indicate that different water level controls can modify $\mathrm{NH}_{4}^{+}-\mathrm{N}$ and $\mathrm{NO}_{3}^{-}-\mathrm{N}$ concentrations in the surface drainage of paddy fields. After each rainstorm, the concentrations of $\mathrm{NH}_{4}^{+}-\mathrm{N}$ and $\mathrm{NO}_{3}^{-} \mathrm{N}$ in $\mathrm{CTD}$ were lower than in the CVD. Differences in the concentrations of $\mathrm{NH}_{4}^{+}-\mathrm{N}$ and $\mathrm{NO}_{3}^{-}-\mathrm{N}$ in the different water level control treatments were significant (Table 3). After each rainstorm, the different water level controls associated with CVD and CTD had significant effects on the $\mathrm{NH}_{4}^{+}-\mathrm{N}$ and $\mathrm{NO}_{3}^{-}-\mathrm{N}$ concentrations. These results differ from earlier (2012) research [27]. This is likely due to different water level controls resulting in different amounts of leakage. In this field experiment the water level controls of CVD and CTD 
had relatively larger differences in leakage compared to leakage in the plot experiment.

\section{Nitrogen Loss Amounts}

$\mathrm{NH}_{4}^{+}-\mathrm{N}$ was the main source of $\mathrm{N}$ losses in the different paddy field drainage modes, while the $\mathrm{NO}_{3}^{-}-\mathrm{N}$ contributed relatively little (Table 4). In CVD, mean $\mathrm{NH}_{4}^{+}-\mathrm{N}$ loss was $5.80 \mathrm{~kg} \mathrm{ha}^{-1}$, accounting for $53.70 \%$ of total nitrogen (TN). In CTD mean loss was $1.93 \mathrm{~kg} \mathrm{ha}^{-1}$, accounting for $53.61 \%$. This was $3.87 \mathrm{~kg} \mathrm{ha}^{-1}$ less than CVD, and the reduction was $66.72 \%$. In $\mathrm{CVD}$, mean $\mathrm{NO}_{3}^{-}-\mathrm{N}$ loss was $0.63 \mathrm{~kg} \mathrm{ha}^{-1}$, accounting for $5.83 \%$ of $\mathrm{TN}$, while in CTD it was $0.28 \mathrm{~kg} \mathrm{ha}^{-1}$, accounting for $7.78 \%$. This was $0.35 \mathrm{~kg} \mathrm{ha}^{-1}$ less than that in CVD, and reduction was $55.56 \% . \mathrm{NH}_{4}{ }^{+} \mathrm{N}$ loss in paddy field drainage was affected by fertilizer level and irrigation management modes. At the same fertilizer level, CTD can more effectively reduce $\mathrm{NH}_{4}^{+}-\mathrm{N}$ loss in paddy fields than $\mathrm{CVD}$. $\mathrm{NO}_{3}^{-}-\mathrm{N}$ loss was relatively lower, which was mainly because the $\mathrm{NO}_{3}^{-}-\mathrm{N}$ content in paddy soil was lower. $\mathrm{NO}_{3}^{-}-\mathrm{N}$ in drainage was mainly from wheat biomass remains, rainfall, and irrigation, while during the rice season $\mathrm{NO}_{3}^{-}-\mathrm{N}$ content was lower. This was mainly because the rice field was flooded and soil was under reducing conditions. Under these conditions, there was low soil oxygen content, low nitrifying bacteria activity, and low nitrification rate, resulting in a small part of nitrogen fertilizer converting to $\mathrm{NO}_{3}^{-}-\mathrm{N}$ after converting to $\mathrm{NH}_{4}^{+}-\mathrm{N}$.

\section{Simulation of $\mathrm{NH}_{4}^{+}-\mathrm{N}$ and $\mathrm{NO}_{3}^{-}-\mathrm{N}$ Concentrations Using the DRAINMOD-N II Model}

The crop water demand during the heading-flowering stage of rice is relatively high. On 2 September the daily rainfall reached its highest level and it was typical rainfall weather. Thus, the second rainstorm was selected as being typical. $\mathrm{NH}_{4}^{+}-\mathrm{N}$ and $\mathrm{NO}_{3}^{-}-\mathrm{N}$ concentrations were continuously measured during the four days after rainstorms. $\mathrm{NH}_{4}^{+}-\mathrm{N}$ and $\mathrm{NO}_{3}^{-}-\mathrm{N}$ concentrations of CVD and CTD were simulated using the DRAINMOD-N II model. Model input data including soil, meteorological,
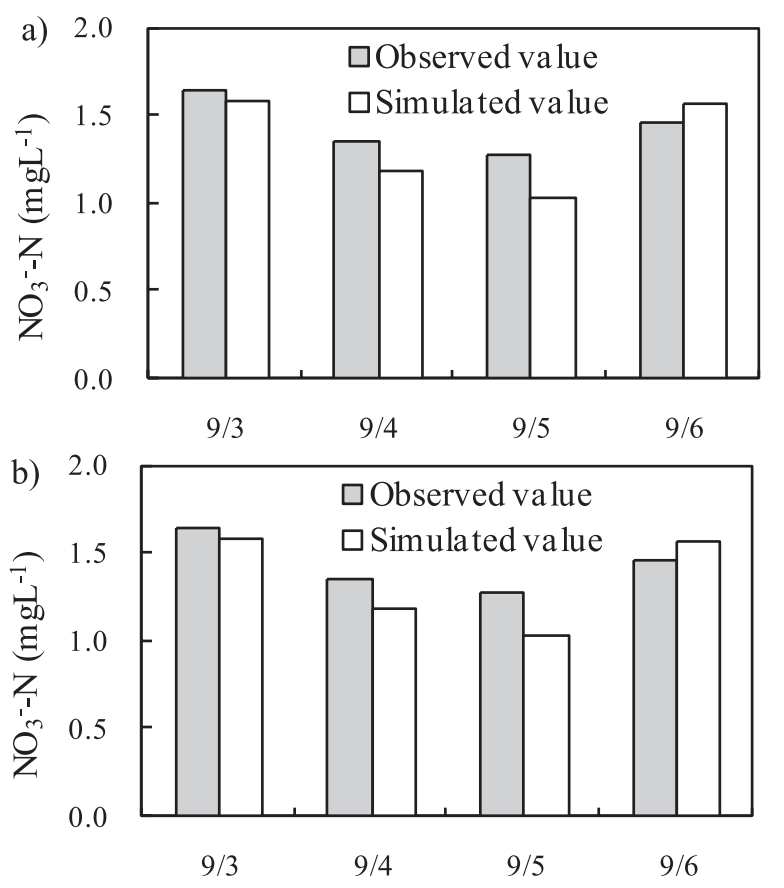

Fig. 4. Observed and simulated value of $\mathrm{NO}_{3}^{-}-\mathrm{N}$ concentrations in different water level controls: a) rainstorm-2-CVD, b) rainstorm-2-CTD.

crop, drainage system design, and nitrogen transport parameters are listed in Tables 5 and 6 .

Observed and simulated values of $\mathrm{NH}_{4}^{+}-\mathrm{N}$ concentrations with different water level controls are shown in Fig. 3. On 6 September the simulated results of $\mathrm{NH}_{4}^{+}-\mathrm{N}$ concentration were decreased by $1.0 \%$ compared with those on 3 September in CVD mode, while the simulated results of $\mathrm{NH}_{4}^{+}-\mathrm{N}$ concentration were decreased by $25.7 \%$ in CTD mode. This indicated that the observed and simulated values of $\mathrm{NH}_{4}^{+}-\mathrm{N}$ concentration in CVD and CTD were similar and the simulation result was good.

Observed and simulated values of $\mathrm{NO}_{3}^{-}-\mathrm{N}$ concentration in different water level control are shown in Fig. 4. On 6 September the simulation results of

Table 7. Simulation evaluation parameter statistics with different water level controls.

\begin{tabular}{|c|c|c|c|c|c|}
\hline Treatment & $\begin{array}{c}\text { Observed value } \\
(\mathrm{mg} / \mathrm{L})\end{array}$ & $\begin{array}{c}\text { Simulated value } \\
(\mathrm{mg} / \mathrm{L})\end{array}$ & $\begin{array}{c}\text { Relative error } \\
(\%)\end{array}$ & $\begin{array}{c}\text { Correlation } \\
\text { coefficient } \mathrm{R}\end{array}$ & $\mathrm{CD}$ \\
\hline $\mathrm{NH}_{4}^{+}-\mathrm{N}$ in rainstorm-2-CVD & 2.97 & 3.28 & 10.44 & 0.95 & 0.32 \\
\hline $\mathrm{NH}_{4}^{+}-\mathrm{N}$ in rainstorm-2-CTD & 5.72 & 5.21 & 8.92 & 0.89 & 0.23 \\
\hline $\mathrm{NO}_{3}^{-}-\mathrm{N}$ in rainstorm-2-CVD & 3.99 & 3.31 & 17.04 & 0.79 & 0.56 \\
\hline $\mathrm{NO}_{3}^{-}-\mathrm{N}^{-}$in rainstorm-2-CTD & 3.94 & 3.98 & 1.02 & 0.71 & 0.23 \\
\hline Total $\mathrm{NH}_{4}^{+}-\mathrm{N}$ in rainstorm-CVD & 23.03 & 22.02 & 4.39 & 0.88 & 1.55 \\
\hline Total $\mathrm{NH}_{4}^{+}-\mathrm{N}$ in rainstorm-CTD & 16.93 & 14.59 & 8.98 & 0.83 & 1.85 \\
\hline Total $\mathrm{NO}_{3}^{-}-\mathrm{N}$ in rainstorm-CVD & 16.29 & 15.80 & 3.01 & 0.59 & 2.12 \\
\hline Total $\mathrm{NO}_{3}^{-}-\mathrm{N}$ in rainstorm-CTD & 10.97 & 11.88 & 8.30 & 0.91 & 1.66 \\
\hline
\end{tabular}


$\mathrm{NO}_{3}^{-}-\mathrm{N}$ concentration were decreased by $19.5 \%$ compared with those on 3 September in CVD mode. The simulation results of $\mathrm{NH}_{4}^{+}-\mathrm{N}$ concentration were decreased by $44.2 \%$ in CTD mode. This indicated that the simulation results were similar to the observed values.

The simulation evaluation indicators are listed in Table 7. The relative errors of total $\mathrm{NH}_{4}^{+}-\mathrm{N}$ and $\mathrm{NO}_{3}^{-}-\mathrm{N}$ concentrations in CTD had relatively larger fluctuations than those in CVD. This is probably because the model is sensitive to changes of precipitation and elevation retaining weir. In simulation of the shorter sequence, the relative errors of both CVD and CTD mode increased. However, with the four precipitation series combined, the total relative error was lower. Except for the correlation coefficient and $\mathrm{CD}$ index of $\mathrm{NO}_{3}^{-}-\mathrm{N}$ in $\mathrm{CVD}$ mode that had relatively greater variability, the simulation results of the other evaluation indexes were reasonable. Limitations of experimental observation accuracy and deviation resulting from the selection of some model parameters were the main reason for this phenomenon. Therefore, the experimental means used to measure the parameters of the observed data should be increased in future work. The results demonstrate that the DRAINMOD model can effectively describe the paddy field drainage and nitrogen process. It is an important method for figuring out suitable water management practices, and that is significant for improving water and fertilizer efficiency and preventing non-point source pollution.

\section{Conclusions}

CTD can effectively reduce $\mathrm{NH}_{4}^{+}-\mathrm{N}$ and $\mathrm{NO}_{3}^{-}-\mathrm{N}$ concentrations in rice field drainage. Four days after a rainstorm, the mean $\mathrm{NH}_{4}^{+}-\mathrm{N}$ and $\mathrm{NO}_{3}{ }^{-} \mathrm{N}$ concentrations in CVD were, respectively, $1.28-1.53 \mathrm{mg} \mathrm{L}^{-1}$ and 0.94-1.11 $\mathrm{mg} \mathrm{L}^{-1}$, while in CTD they were $0.95-1.08 \mathrm{mg} \mathrm{L}^{-1}$ and 0.61-0.74 $\mathrm{mg} \mathrm{L}^{-1}$. Compared with $1 \mathrm{~d}$ after a rainstorm, $\mathrm{NH}_{4}^{+}-\mathrm{N}$ and $\mathrm{NO}_{3}^{-}-\mathrm{N}$ concentrations, respectively, decreased by $28.7-46.7 \%$ and $37.5-47.5 \%$ at $4 \mathrm{~d}$ in CTD, which was significantly greater than in CVD. Significant differences in $\mathrm{NH}_{4}^{+}-\mathrm{N}$ and $\mathrm{NO}_{3}{ }^{-} \mathrm{N}$ concentrations under different water level control conditions were found.

The mean $\mathrm{NH}_{4}^{+}-\mathrm{N}$ and $\mathrm{NO}_{3}^{-}-\mathrm{N}$ losses were $1.93 \mathrm{~kg} \mathrm{ha}^{-1}$ and $0.28 \mathrm{~kg} \mathrm{~kg} \mathrm{ha}^{-1}$, reducing $3.87 \mathrm{~kg} \mathrm{ha}^{-1}$ and $0.35 \mathrm{~kg} \mathrm{ha}^{-1}$, compared to CVD, and the reductions were, respectively, $66.72 \%$ and $55.56 \%$. $\mathrm{NH}_{4}^{+}-\mathrm{N}$ contributed the most to nitrogen loss while $\mathrm{NO}_{3}^{-}-\mathrm{N}$ contribution was less.

The DRAINMOD- II model was used to simulate the $\mathrm{NH}_{4}^{+}-\mathrm{N}$ and $\mathrm{NO}_{3}^{-}-\mathrm{N}$ under the $\mathrm{CVD}$ and $\mathrm{CTD}$ treatments. At $4 \mathrm{~d}$ after a rainstorm, the simulated $\mathrm{NH}_{4}^{+}-\mathrm{N}$ and $\mathrm{NO}_{3}{ }^{-}-\mathrm{N}$ concentrations were decreased by $1.0 \%$ and $19.5 \%$, respectively, compared with $1 \mathrm{~d}$ in the CVD mode. In contrast, the simulated results of $\mathrm{NH}_{4}^{+}-\mathrm{N}$ concentration were decreased by $25.7 \%$ and $44.2 \%$ in the CTD treatment. This indicated that the observed and simulated values of $\mathrm{NH}_{4}^{+}-\mathrm{N}$ and $\mathrm{NO}_{3}^{-}-\mathrm{N}$ concentrations in CVD and CTD were similar and the simulation results were good.
In summary, this study focused on nitrogen concentrations and load changes in paddy drainage under storms in different irrigation and drainage modes. The DRAINMOD-N II model was used to simulate $\mathrm{NH}_{4}^{+}-\mathrm{N}$ and $\mathrm{NO}_{3}-\mathrm{N}$ concentration changes under field scales. The results can be used to improve drainage systems and water level controls in farmlands. They can also help improve the irrigation-drainage system of paddy rice and provide a scientific basis for optimizing irrigation-drainage project design in rice irrigation districts.

\section{Acknowledgements}

Our research was financially supported by the National Natural Science Foundation of China (No. 51409124, 51409126, 41401628 and 51679108), the Natural Science Foundation of Jiangsu Province, China (No. BK20140564).

\section{References}

1. CHIRINDA N., CATER M.S., ALBERTB K.R., AMBUS P., OLESEN J.E., PORTER J.R., PETERSEN S.O. Emissions of nitrous oxide from arable organic and conventional cropping systems on two soil types. Agriculture Ecosystems \& Environment. 136, 199, 2010.

2. VALDEMARSEN T., QUINTANA C.O., FLINDT M.R., KRISTENSEN E. Organic $\mathrm{n}$ and $\mathrm{p}$ in eutrophic fjord sediments-rates of mineralization and consequences for internal nutrient loading. Biogeosciences. 12, 1765, 2015.

3. JANMOHAMMADI M., AMANZADEH T., SABAGHNIA N., ION V. Effect of nano-silicon foliar application on safflower growth under organic and inorganic fertilizer regimes. Botanica Lithuanica. 22, 53, 2016.

4. LI H., LIANG X.Q., CHEN Y.X., TIAN G.M., ZHANG Z.J. Ammonia volatilization from urea in rice fields with zero-drainage water management. Agricultural Water Management. 95, 887, 2008.

5. BELDER P., BOUMAN B.A.M., CABANGON R., GUOAN L., QUILANG E.J.P., LI Y.H., SPIERTZ J.H.J., TUONG T.P. Effect of water-saving irrigation on rice yield and water use in typical lowland conditions in Asia. Agricultural Water Management. 65, 193, 2004.

6. PENG S.Z., YANG S.H., XU J.Z., LUO Y.F., HOU H.J. Nitrogen and phosphorus leaching loss from paddy field with different water and nitrogen management. Paddy and water environment. 9, 333, 2011.

7. GUO L., NING T., NIE L., LI Z., LAL R. Interaction of deep placed controlled-release urea and water retention agent on nitrogen and water use and maize yield. European Journal of Agronomy.75, 118, 2016.

8. LEO J.M., BOUMANS D.F., GERARD V.D. Nitrate leaching in agriculture to upper groundwater in the sandy regions of the Netherlands during the 1992-1995 period. Environmental Monitoring and Assessment. 102, 225, 2005.

9. YANG L., HUANG J.S., ZHAO L., HUANG Z.Q. Experimental study on the distribution of soil nitrate and ammonium nitrogen under controlled drainage. Wuhan University Journal of Natural Sciences. 14, 532, 2009. 
10. MILLER J., CHANASYK D., CURTIS T., ENTZ T., WILLMS W. Influence of streambank fencing with a cattle crossing on riparian health and water quality of the lower little bow river in southern alberta, canada. Agricultural Water Management. 97, 247, 2010.

11. GRANATH G., LIMPENS J., POSCH M., MÜCHER S., VRIES W.D. Spatio-temporal trends of nitrogen deposition and climate effects on sphagnum, productivity in european peatlands. Environmental Pollution. 187, 73, 2014.

12. HASHEMIF., OLESEN J.E., DALGAARDT., BØRGESEN, C.D. Review of scenario analyses to reduce agricultural nitrogen and phosphorus loading to the aquatic environment. Science of the Total Environment. 573, 608, 2016.

13. DRECHT G.V., BOUWMANN A.F., KNOOP J.M., MEINARDI C., BEUSEN A. Global pollution of surface waters from point and nonpoint sources of nitrogen. The Scientific World Journal. 2, 632, 2001.

14. OLAREWAJU O.E., ADETUNJI M.T., ADEOFUN C.O., ADEKUNLE I.M. Nitrate and phosphorus loss from agricultural land: implications for nonpoint pollution. Nutrient Cycling in Agroecosystems. 85, 79, 2009.

15. SALAZAR O., WESSTRÖM I., JOEL A. Evaluation of drainmod using saturated hydraulic conductivity estimated by a pedotransfer function model. Agricultural Water Management. 95, 1135, 2008.

16. WANG S.L., PRASHER S.O., PATEL R.M. Fate and transport of nitrogen compounds in a cold region soil using DRAINMOD. Computers and Electronics in Agriculture. 53, 113, 2006.

17. AMSALU T., MENGAW A. Gis based soil loss estimation using rusle model: the case of jabi tehinan woreda, anrs, ethiopia. Natural Resources. 5, 616, 2014.

18. TAKEOKA M., JIN R.B., SASAKI M. Full analysis of multi-photon pair effects in spontaneous parametric down conversion based photonic quantum information processing. New Journal of Physics. 17, 253, 2015.
19. WANG S.L., WANG X.G., LARRY C.B. Current Status and Prospects of Agricultural Drainage in China. Irrigation and Drainage. 56, 47, 2007.

20. TIAN S., YOUSSEF M.A., SKAGGS R.W., AMATYA D.M., CHESCHEIR G.M. Drainmod-forest: integrated modeling of hydrology, soil carbon and nitrogen dynamics, and plant growth for drained forests. Journal of Environmental Quality. 41, 764, 2012.

21. GILLIAM J.W., CHESCHEIR G.M., SKAGGS R.W., YOUSSEF M.A. The nitrogen simulation model, DRAINMOD-N II. Transactions of the ASAE. 48, 611, 2005.

22. BECHTOLD I., KÖHNE S., YOUSSEF M.A., LENNARTZ B., SKAGGS, R.W. Simulating nitrogen leaching and turnover in a subsurface-drained grassland receiving animal manure in northern germany using DRAINMOD-N II. Agricultural Water Management. 93, 30, 2007.

23. SEPA (State of Environmental Protection Association). Environmental Quality Standard for Surface Water. GB3838-2002, P.R.China, 2002.

24. CUI Y.L., LI Y.H., LU G.A., SHA Z.R. Nitrogen move ment andtransformation with different water supply for paddy rice. Advances in Water Science. 15, 280, 2004.

25. XIAO M.H., YU S.E., ZHANG Y.L. Changes of nitrogen concentration for surface and groundwater in flooding paddy field under controlled drainage. Transactions of the Chinese Society of Agricultural Engineering. 27, 180, 2011.

26. XIAO M.H., YU S.E., SHE D.L. Technical standards of irrigation and drainage management in paddy field of watersaving and pollution-reduction with high yield. Journal of Food, Agriculture Environment. 10, 1005, 2012.

27. XIAO M. H., YU S. E., WANG Y.Y., HUANG R. Nitrogen and phosphorus change and optimal drainage time of flooded paddy field based on environmental factors. Water science and engineering. 6, 164, 2013. 
